\title{
Field stratification of antelope bitterbrush seeds
}

\author{
JAMES A. YOUNG, J. ROSS WIGHT, AND JAMES E. MOWBRAY
}

\begin{abstract}
First author is range scientist, USDA-ARS, Landscape Ecology of Rangelands, 920 Valley Rd., Reno, Nev. 89512; second and third authors are range scientists, Northwest Watershed Research Center, 800 Park Blvd., Plaza IV, Suite 105, Boise, Ida. 83705 .
\end{abstract}

\begin{abstract}
The germination ecology of antelope bitterbrush [Purshia tridentata (Pursh) Nutt.] seed has probably been investigated more than any other range shrub. Seeds of this valuable browse species are known to require moist prechilling before they will germinate. Our purpose was to investigate the nature of this dormancy breaking by placing packages ( $2 \times 2-\mathrm{mm}$ mesh screen) of seeds on the surface and buried in the seedbed at several locations in Idaho and Nevada and to recover the seeds monthly through the winter. The seeds were categorized based on their being: (a) capable of germinating; (b) dormant; or (c) dead at each recovery. The seedbeds of the $\mathbf{2}$ sites in Nevada, during 2 years of drought, were not sufficiently wet to bring large amounts of the antelope bitterbrush seeds out of dormancy. The seeds did not rot in the field, and being protected from predation, they remained dormant in the seedbed. The highest elevation site in Idaho had as high as $80 \%$ of the seeds lose dormancy. If seedbed microenvironmental conditions were satisfactory, the inherent seed dormancy was lost by midwinter. Snow cover, as it influences seedbed moisture and temperatures, apparently is an important factor in the prechilling of antelope bitterbrush seeds.
\end{abstract}

Key Words: browse regeneration, seed and seedbed ecology, microenvironment

Antelope bitterbrush [Purshia tridentata (Pursh) Nutt.]) is one of the most important browse species on western rangelands in North America. Widely distributed in the more arid portions of the Sierra-Cascade and Rocky Mountains and the Intermountain area, antelope bitterbrush provides valuable browse for domestic and wild animals. Natural and artificial regeneration of this species, especially on winter ranges, is a major problem for range managers.

Hormay (1943) reported that seeds of antelope bitterbrush required a period of incubation under cool, moist conditions before they would germinate. This type of seed dormancy is known as a stratification requirement, from classical German forestry techniques required to break the dormancy. Modern seed technologists prefer the self-evident term prechilling requirement. Many economically important species of the rose family are known to have seed dormancy that requires moist prechilling for germination. There is a great deal of published information concerning the physiology of prechilling requirements, but little information concerning the field ecology of the natural process.

Since the discovery of the nature of dormancy of antelope bitterbrush seeds, a variety of chemical treatments have been offered to replace or modify the cool, moist stratification requirement. These include soaking the seeds in an aqueous solution of thiourea (Pearson 1957), or hydrogen peroxide (Everett and Meeuwig 1957), or enrichment of the germination substrate with gibberellic acid (McConnell 1960). Detailed laboratory experiments have

\footnotetext{
Manuscript accepted 17 Jan. 1993.
}

defined the temperature limits of the antelope bitterbrush requirement ( 0 to $5^{\circ} \mathrm{C}$ with $2^{\circ} \mathrm{C}$ optimum) (Young and Evans 1976).

Our purpose was to place seeds of antelope bitterbrush in field seedbeds at various geographic locations of the Intermountain area in the late fall and recover seeds periodically during winter and determine the germination characteristics of the seeds.

\section{Materials and Methods}

Seeds of antelope bitterbrush were obtained from commercial seed lots collected at the Boise Front, Ida. They were collected from the same stands and processed by the same commercial threshing and cleaning equipment. The experimental design consisted of 4 replications of 100 seeds each arranged in a randomized block design. Seeds were placed in the field in $10 \times 10-\mathrm{cm}$ packets made of galvanized screen with $2 \times 2-\mathrm{mm}$ openings. Packets were either placed on the soil surface or buried $2.5 \mathrm{~cm}$ deep in the surface soil. The natural surface soil at each location was used except at Reno, Nev., where greenhouse flats, $40 \times 50 \times 10 \mathrm{~cm}$, were filled with surface soil from the Granite Peak, Nev., location. The flats were buried so their surface was the same level as the surrounding soil surface.

The packets of seeds were placed in the field in late October of 1987 and 1988. Packets were recovered monthly through 1 May of the following year. Packets were placed at 3 locations in the Reynolds Creek Watershed of the Northwest Watershed Research Center, located in the Owyhee Mountains, south of Boise, Ida. In Nevada, experimental locations were Reno and Granite Peak, located $50 \mathrm{~km}$ north of Reno (Tables 1 and 2).

The amount of snow cover on the seed packages in the field was ocularly estimated if discontinuous, and the snow depth measured. Soil frost was determined on plots without snow cover with frost tubes, and where snow depth made this impossible, with gypsum blocks buried at the soil surface. Frozen blocks produce high resistance.

Upon recovery, the seed packets were opened and the seeds classified as germinated if the radicle was emerged $2 \mathrm{~mm}$. Ungerminated seeds were placed on germination paper in petri dishes and moistened with tap water. The seeds were incubated at $15^{\circ} \mathrm{C}$ for 2 weeks in dark incubators. Germinated seeds were counted weekly. At the end of the incubation period, seeds that were covered with fungal mycelium and were soft were considered dead. Seeds that remained firm and ungerminated were considered dormant.

Analysis of variance (ANOVA) was used on percentage germination with arc sin square root transformation after Hartley's F-max test of homogeneity of variance was performed to determine if it was appropriate.

\section{Results and Discussion}

In a very simple algorithm of what would be necessary to develop a model for the germination of seeds of antelope bitterbrush, the seeds are always in 1 or more of 3 categorics: (a) capable 
Table 1. Physical characteristics of sites where the field stratification was conducted in Nevada and Idaho.

\begin{tabular}{lllcc}
\hline \hline & & Soils & & Elevation \\
Location & Group & Surface texture & $\begin{array}{c}\text { Mean annual } \\
\text { precipitation }\end{array}$ \\
\hline Reynolds Creek, Ida. & & & (mm) & $(\mathrm{mm})$ \\
Quonset & Xerollic Haplargids & gravelly loam & 1195 & 230 \\
Lower Sheep Creek & Pachic Argixerolls & silt loam & 1660 & 340 \\
Upper Sheep Creek & Pachic Cryoboroll & silt loam & 1880 & 500 \\
Reno, Nev. & Typic Haplargids & sandy loam & 1385 & 180 \\
Granite Peak, Nev. & Typic Haplargids & sandy loam & 1850 & 250 \\
\hline
\end{tabular}

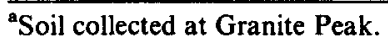

Table 2. Plant communities of the sites where the field stratification was conducted in Nevada and Idaho.

\begin{tabular}{|c|c|c|}
\hline Location & Plant community & $\begin{array}{l}\text { Natural antelope } \\
\text { bitterbrush site }\end{array}$ \\
\hline \multicolumn{3}{|c|}{ Reynolds Creek, Ida. } \\
\hline Quonset & $\begin{array}{l}\text { Artemisia tridentata ssp. } \\
\text { wyomingensis / Elytrigia spicata }\end{array}$ & yes \\
\hline $\begin{array}{l}\text { Lower Sheep } \\
\text { Creek }\end{array}$ & $\begin{array}{l}\text { Artemisia tridentata ssp. } \\
\text { wyomingensis / Elytrigia spicata }\end{array}$ & yes \\
\hline $\begin{array}{l}\text { Upper Sheep } \\
\text { Creek }\end{array}$ & $\begin{array}{l}\text { Populus tremuloides-Artemisia } \\
\text { tridentata ssp. vaseyana/Elytrigia } \\
\text { spicata }\end{array}$ & no \\
\hline $\begin{array}{l}\text { Reno, Nev. } \\
\text { Granite Peak, Nev. }\end{array}$ & $\begin{array}{l}\text { No natural plant community } \\
\text { Artemisia tridentata ssp. } \\
\text { vaseyana/ Stipa thurberiana }\end{array}$ & $\begin{array}{l}\text { no } \\
\text { yes }\end{array}$ \\
\hline
\end{tabular}

of germination if placed in a suitable environment; (b) dormant in any environment; (c) nonviable or dead (Table 3). Obviously the proportion of the seed populations in each of these categories changes over winter. The 3 seed parameters of germinable (capable of germinating), dormant, and dead appear very simple, but their interactions with year of seed production, site, and burial become complex.

\section{Initial Seed Population}

In this study we started with seed populations with 5 and $4 \%$ germination, and over $99 \%$ viability (as indicated on seed tag) for 1986 and 1987 , respectively. Comparing the overall average results by recovery dates revealed no significant $(P=0.01)$ differences between the years for the 3 germination parameters (data not shown). As the data presentation develops it will be clear that this similarity in the overall averages between years is apparently a function of compensating variability rather than statistical precision.

In repeated experiments, the initial seed population never has the same physiological characteristics. Even in the most careful seed storage conditions, seeds from the same lot change over time. Kay et al. (1988) provides numerous examples of germination declines, enhancement, and cyclic responses for seeds of native shrubs. There are so many environmental influences on seed production in native plant stands, germination responses for various parameters are seldom identical. Young and Evans (1989) provide detailed studies of this phenomena for sceds of basin big sagebrush (Artemisia tridentata ssp. tridentata) repeatedly collected from native stands and grown in reciprocal common gardens. After this study was completed, Susan Meyer (1989) demonstrated in an innovative study that incubation temperatures from maturity to the time of germination influenced the nature of cool-moist chilling requirements for seeds of antelope bitterbrush. Until they were placed in the field, the seeds in this study were stored in 1 lot, but once placed in the field variable temperatures dependent on the site came into play.

\section{Seed Burial}

Germination of seeds of antelope bitterbrush was significantly $(P=0.01)$ higher with seed burial versus on the surface of the seedbed at all recovery dates except December and March (Table 3). In December, the seeds did not have their prechilling requirements completely satisfied and March would be the optimum time for bitterbrush emergence in nature (Young and Evans 1981). The higher germination of the seeds recovered from the surface in the March recovery was due to the very high germination of seeds recovered from the surface of seedbeds at the Upper Sheep Creek site. Deep snow cover at this site apparently canceled the negative influence of the surface environment. The harshness of surface seedbeds in temperate desert environments has been well quantified both for extremes in fluctuating temperatures and moisture stress (Evans and Young 1970, 1972). Remember the seeds in this study were not naked on the soil surface, but were placed in screen packages that partially modified the harshness of the surface environment.

Lower Sheep Creek in the Reynolds Creek watershed is a natural site for antelope bitterbrush (Table 2). Detailed comparison of seed germination for surface and buried seeds illustrates how harsh the surface environment can be at this site (Fig. 1). Only in 1 monthly sample in the 2 years of the study did seeds placed in screen

Table 3. Changes over time in the characteristics of antelope bitterbrush seeds recovered from the field. Overall averages of surface and buried seeds at all sites and both years for monthly recoveries from December through May. ${ }^{a}$

\begin{tabular}{|c|c|c|c|c|c|c|c|}
\hline \multirow[b]{2}{*}{ Seed characteristics } & \multirow[b]{2}{*}{ Initial seed } & \multicolumn{6}{|c|}{ Recovery date } \\
\hline & & Dec. & Jan. & Feb. & March & April & May \\
\hline \multicolumn{7}{|l|}{ Germination } & \\
\hline Field & - & $1(7)$ & $8(6)$ & $17(5)$ & $25(5)$ & $26(8)$ & $20(5)$ \\
\hline Laboratory & $4(2)$ & $7(6)$ & $18(3)$ & $17(3)$ & $16(8)$ & $8(4)$ & $2(5)$ \\
\hline Total & $4(2)$ & $8(2)$ & $26(4)$ & $34(5)$ & $41(5)$ & $34(6)$ & $22(8)$ \\
\hline Dormant & $96(6)$ & $90(9)$ & $66(11)$ & $64(9)$ & $57(10)$ & $53(12)$ & 58 (14) \\
\hline Dead & $0(3)$ & $2(5)$ & $8(10)$ & $6(9)$ & $2(10)$ & $13(6)$ & $23(5)$ \\
\hline
\end{tabular}

${ }^{\mathrm{a}}$ Means given with confidence interval (0.01 level of probability) in parenthesis (Evans et al. 1982). 

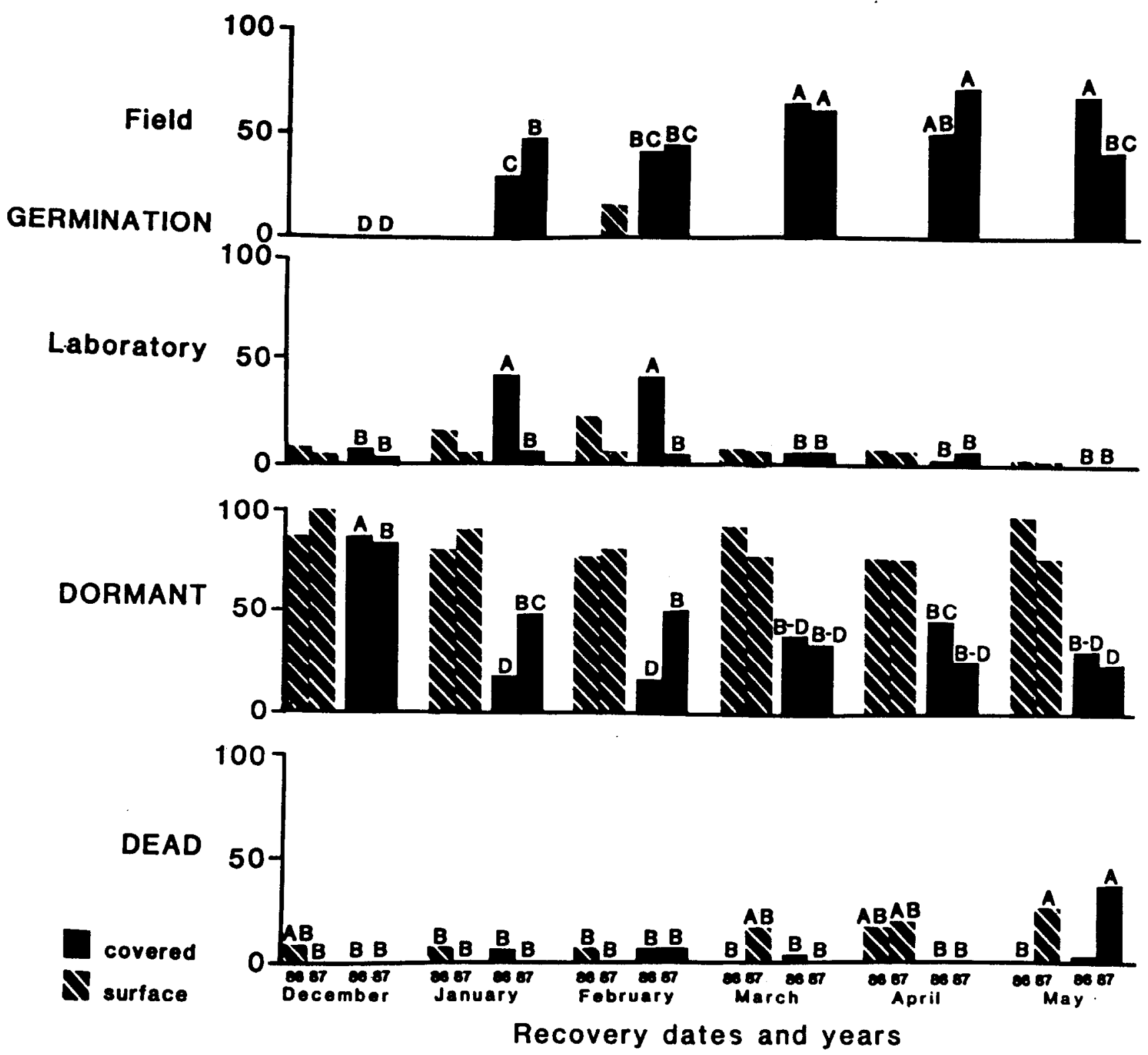

Fig. 1. Percentage field and laboratory germination, dormant and dead seeds of antelope bitterbrush at the Lower Sheep Creek locations of Reynolds Creek, Ida. Seeds recovered monthly from December to May 1986-87 and 1987-88. Seeds recovered from the surface of the soil or buried $2.5 \mathrm{~cm}$ deep. Columns within seed characteristics and burial types with the same letter are not significantly different at the 0.01 level of probabllity as determined by confidence intervals calculated from regression equations. No letters indicate no significant differences.

packages on the soil surface germinate in the field. Buried seeds had optimum field germination in the spring from March to May. Comparing field and laboratory germination over time at Lower Sheep Creek demonstrates that germination on the soil surface was not the primary problem for the seeds of antelope bitterbrush. The failure of the surface seeds to germinate was due to their unsatisfied cool-moist prechill requirements. Over the course of both winters, the seeds on the soil surface never had a significant $(P=0.01)$ reduction in the percentage of dormant seeds (Fig. 1). Buried seeds at Lower Sheep Creek had either germinated or were ready to germinate by January, at a rate of 70 and $50 \%$ for 1986-87 and 1987-88, respectively.

At both of the Nevada locations, the failure of the antelope bitterbrush seeds to meet cool-moist prechilling conditions on the soil surface was even more pronounced than at Lower Sheep Creek (data not shown). To obtain the proper perspective of these germination dynamics, remember that we are defining germination as the radicle emerged $2.0 \mathrm{~mm}$. Germinated does not mean a leafy antelope bitterbrush seedling waving in the breeze, but rather extremely slow root elongation under very cold conditions. Low seed mortality until late in the spring illustrates how slow the

Table 4. Comparison of seeds placed on surface or buried $2.5 \mathrm{~cm}$ deep. Average (\%) of all sites and both years for the percentage of seeds of antelope bitterbrush that germinated in the field and laboratory for monthly recoveries from December through May. ${ }^{a}$

\begin{tabular}{lcccccc}
\hline \hline Seed & \multicolumn{5}{c}{ Recovery date } \\
\cline { 2 - 7 } burial & Dec. & Jan. & Feb. & March & April & May \\
\hline Surface & 9 & $24 \mathrm{~b}$ & $23 \mathrm{~b}$ & 35 & $23 \mathrm{~b}$ & $7 \mathrm{~b}$ \\
$2.5 \mathrm{~cm}$ & 18 & $35 \mathrm{a}$ & $40 \mathrm{a}$ & 45 & $41 \mathrm{a}$ & $37 \mathrm{a}$ \\
deep & & & & & & \\
\hline
\end{tabular}

"Means within recovery date are not significantly different when followed by the same letter as determined by Duncan's Multiple Range test. No letters indicate no significant differences. 

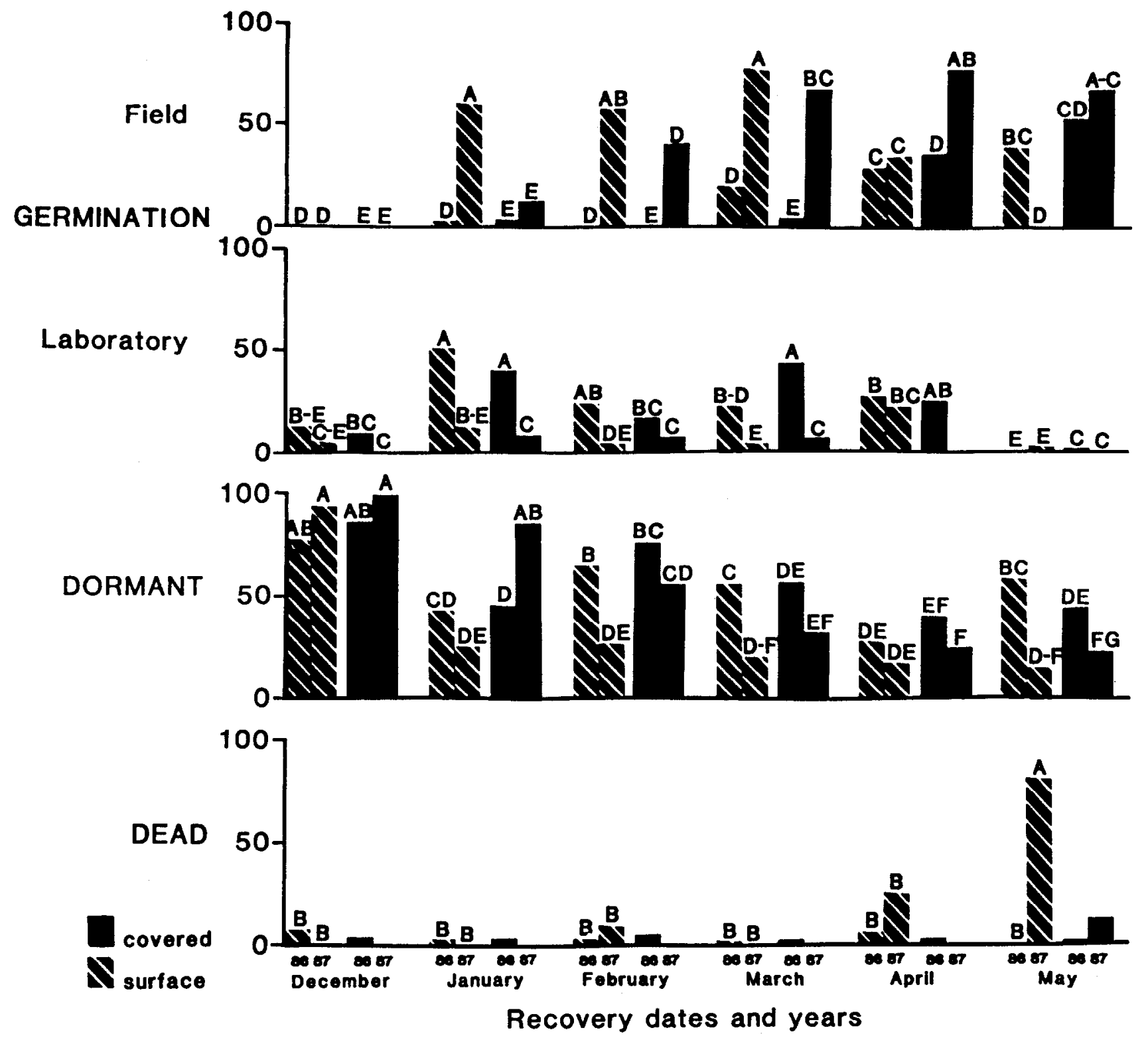

Fig. 2. Percentage fleld and laboratory germination, dormant and dead seeds of antelope bitterbrush at the Upper Sheep Creek locations of Reynolds Creek, Idaho. Seeds recovered monthly from December to May 1986-87 and 1987-88. Columns within seed characteristics and burial types with the same letter are not significantly different at the 0.01 level of probability as determined by confidence intervals calculated from regression equations (Evans et al. 1982). No letters indicate no significant differences.

germination process can be under cold conditions in the field.

Upper Sheep Creek in the Reynolds Creek Watershed is generally above the natural distribution of bitterbrush. The seed placement site was located on a north facing slope where snow drifts normally persist into late spring. The seedbed environment of the Upper Sheep Creek site allowed more than $75 \%$ of the antelope bitterbrush seeds to come out of dormancy and be capable of germination (Fig. 2). This was the highest percentage of any location. The influence of the greater snow cover at Upper Sheep Creek is apparent in the extremes in soil temperatures at this location versus the lowest experimental site in the watershed, Quonset (Fig. 3). In 1987-88 it appeared that the persistent snow cover created a

Table 5. Precipitation during stratification period at field locations.

\begin{tabular}{|c|c|c|c|c|c|c|c|c|c|c|}
\hline & \multicolumn{2}{|c|}{ Quonset } & \multicolumn{2}{|c|}{ Lower Sheep Creek } & \multicolumn{2}{|c|}{ Upper Sheep Creek } & \multicolumn{2}{|c|}{ Reno } & \multicolumn{2}{|c|}{ Granite Peak } \\
\hline & $1986-87$ & $87-88$ & $1986-87$ & $87-88$ & $1986-87$ & $87-88$ & $1986-87$ & $87-88$ & $1986-87$ & $87-88$ \\
\hline & $---\cdot-$ & $-\ldots$ & $-\ldots .$. & ----- & $-\cdots--(c$ & $--\cdots$ & $-\cdots-\cdot$ & ---- & $\cdots \ldots$ & $\cdots-\cdots$ \\
\hline November & 1.2 & 0.8 & 1.4 & 2.1 & 3.0 & 3.8 & 0.9 & 1.1 & 1.4 & 1.6 \\
\hline December & 0.7 & 3.3 & 0.7 & 2.4 & 2.6 & 5.8 & 0.2 & 0.3 & 0.4 & 1.0 \\
\hline January & 2.2 & 2.0 & 2.0 & 2.4 & 5.8 & 7.6 & 0.3 & 0.8 & 0.6 & 0.9 \\
\hline February & 0.7 & 1.4 & 5.4 & 0.7 & 6.4 & 0.8 & 0.1 & 0.4 & 0.4 & 0.8 \\
\hline March & 5.9 & 1.7 & 2.4 & 2.5 & 4.3 & 3.4 & 0.4 & 0 & 0.7 & 0 \\
\hline Total & 10.7 & 9.2 & 11.9 & 10.1 & 21.8 & 21.8 & 1.9 & 2.6 & 3.5 & 4.3 \\
\hline
\end{tabular}




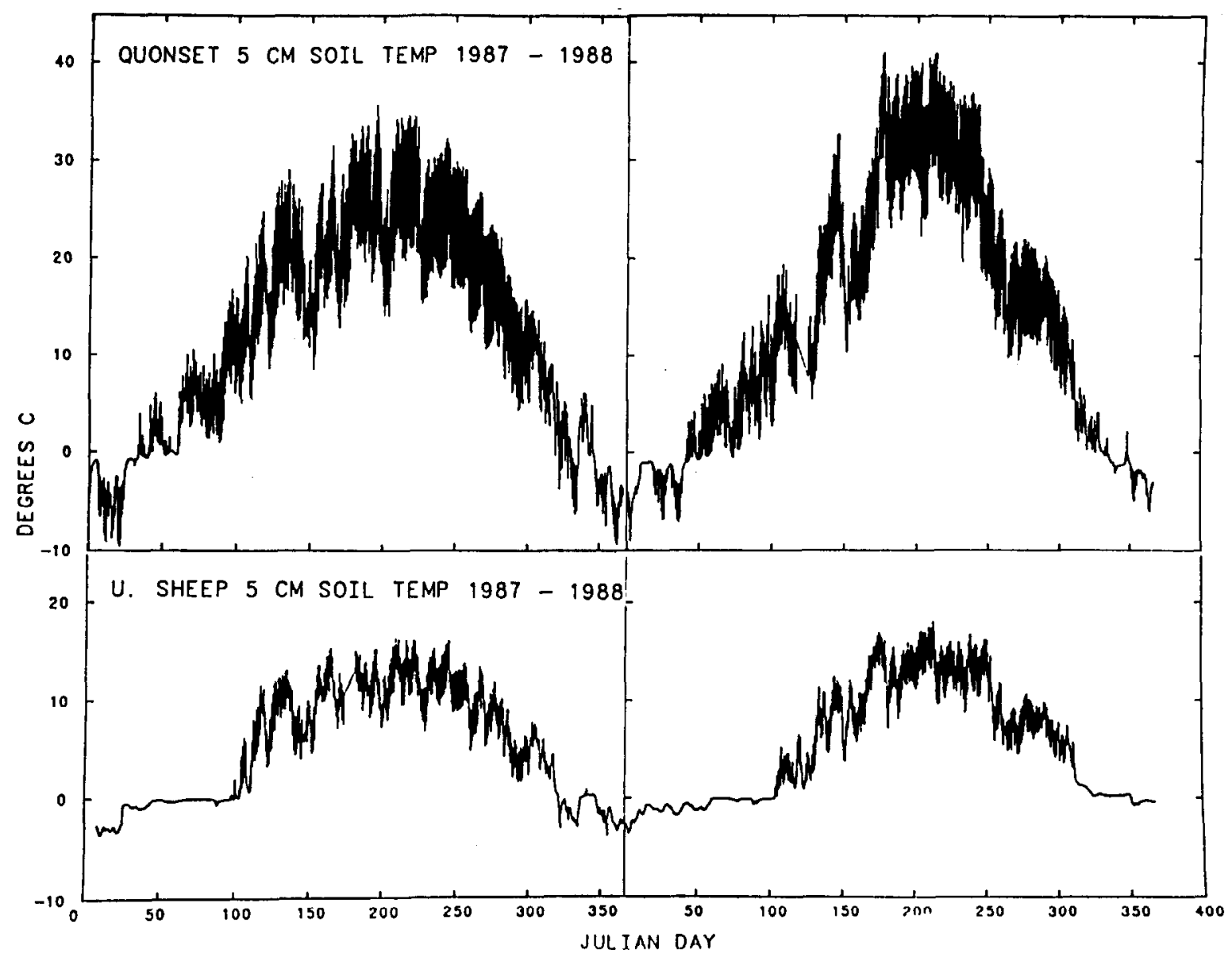

Fig. 3. Soil temperatures at $5 \mathrm{~cm}$ at the Quonset and Upper Sheep Creek locations in Reynolds Creek Watershed 1987-88.

problem because seed mortality reached $80 \%$ with seeds on the surface (Fig. 1). Apparently the germinating seedlings exhaust food reserves while still buried under the snow.

\section{Microenvironmental Relations}

Antelope bitterbrush seedling establishment is generally considered to be difficult to obtain, and especially difficult to attain in the face of competition from such plants as cheatgrass (Bromus tectorum L.) and seed predation by granivores (Nord 1965). This competition is for soil moisture for growth. In the 2 years of this experiment there was not adequate moisture for cool-moist prechilling of antelope bitterbrush seeds during November and December at the 2 Nevada locations (Table 5). Seeds returned to Reno, Nev., had a maximum of $30 \%$ germination. This was in

Table 6. Snow and frost depth and snow cover at Lower Sheep Creek in the Reynolds Creek Watershed 1986-87 and 1987-88.

\begin{tabular}{|c|c|c|c|c|c|c|c|}
\hline \multirow[b]{2}{*}{ Month } & \multirow[b]{2}{*}{ Week } & \multicolumn{2}{|c|}{ Snow depth } & \multicolumn{2}{|c|}{ Snow cover } & \multicolumn{2}{|c|}{ Frost depth } \\
\hline & & $86-87$ & $87-88$ & $86-87$ & $87-88$ & $86-87$ & $87-88$ \\
\hline & & \multicolumn{2}{|c|}{$(\mathrm{cm})$} & \multicolumn{2}{|c|}{$(\%)$} & \multicolumn{2}{|c|}{$(\mathrm{cm})$} \\
\hline November & 4 & $--^{\prime}$ & 0 & - & 0 & - & $0-11$ \\
\hline \multirow[t]{4}{*}{ December } & 1 & 0 & 1.3 & 0 & 100 & 0 & - - \\
\hline & 2 & 3.3 & 0 & 90 & 0 & $0-27$ & $0-20$ \\
\hline & 3 & 3.8 & 2.5 & 6 & 100 & frozen & $0-27$ \\
\hline & 4 & 3.8 & 1.3 & 20 & 100 & $0-40$ & $0-42$ \\
\hline \multirow[t]{4}{*}{ January } & 1 & 21.3 & 18.0 & 100 & 100 & 0-39 & $0-42$ \\
\hline & 2 & 30.0 & 16.3 & 100 & 80 & $0-50$ & $0-5$ \\
\hline & 3 & - - & 21.3 & - & 100 & -- & $0-7$ \\
\hline & 4 & drifts & 11.3 & 75 & 95 & - - & $0-16$ \\
\hline \multirow[t]{4}{*}{ February } & 1 & - & 16.3 & 15 & 100 & 0 & $0-17$ \\
\hline & 2 & - - & 17.8 & 5 & - & $0-12$ & $3-25$ \\
\hline & 3 & 2.0 & 0 & 100 & 0 & 0 & $0-18$ \\
\hline & 4 & 31.3 & 0 & 100 & 0 & $0-14$ & $0-20$ \\
\hline \multirow[t]{4}{*}{ March } & 1 & 30.0 & 0 & 95 & 0 & $0-12$ & $12-18$ \\
\hline & 2 & 0 & 0 & 0 & 0 & 0 & 0 \\
\hline & 3 & 0 & 1.3 & 0 & 100 & 0 & 0 \\
\hline & 4 & 0 & 2.0 & 10 & 90 & 0 & 0 \\
\hline
\end{tabular}

'Samples not collected. 
February 1988, and it resulted in $4 \%$ germination in the field in March (data not shown). The dry November 1987 at the Quonset site in Reynolds Creek resulted in only $2 \%$ of the surface and $25 \%$ of the buried seeds being capable of germinating in January 1988.

Without the protective screen packages used in this study, the populations of antelope bitterbrush seeds would have been almost totally collected, a small portion consumed immediately and the majority cached in scatter hoards, by rodents. Rodent caches are usually about $2.5 \mathrm{~cm}$ deep in the surface soil. Considering the advantage of seed burial over the surface in obtaining the necessary moist prechilling to overcome dormancy, this is a most fortuitous situation and an apparent example of parallel evolution.

The dormancy of antelope bitterbrush seeds is broken by cool incubation of moist seeds, so obviously both temperature and moisture are important in the over-winter seedbeds. Obviously, at the high elevation of Granite Peak, Nev., mid-winter temperatures are very cold in bare seedbeds, but this did not break the dormancy of dry antelope bitterbrush seeds. In experimental studies of the moist prechilling requirements of antelope bitterbrush seeds, it was determined that temperatures below about $-3^{\circ} \mathrm{C}$ were detrimental to breaking dormancy (Young and Evans 1976). Based on observations of comparative success in natural regeneration of antelope bitterbrush plants, it has long been thought that areas with continuous snow cover had better antelope bitterbrush establishment than lower elevation areas. This has been attributed to the environment for moist prechilling provided at the soil surface by the snow cover.

We have snow depth, cover, and frost depth data for the Lower Sheep Creek seed recovery (Table 6). For both years of the study there was no snow cover at the site for the first month the seeds were exposed in the field. For both years less than $10 \%$ of the seeds recovered had germinated or would germinate, and 4 to $6 \%$ of the seed population was germinable when the seeds were placed in the field. Snow depths for December ranged from 0 to $3.8 \mathrm{~cm}$ and 0 to $1.3 \mathrm{~cm}$ for 1986 and 1987 , respectively. The spatial distribution of this snow cover was highly variable over the site (Table 6 ). The soil was frozen to a depth of $42 \mathrm{~cm}$ at certain locations and discontinuous times during December. With seed burial, this variable snow cover and these temperatures were sufficient to bring 70 and $50 \%$ of the antelope bitterbrush seeds to a physiological state where they could germinate, for 1987 and 1988, respectively (Fig. 1). Seeds on the soil surface at Lower Sheep Creek only had 4 to $18 \%$ potential germination during the 2 years in question for January recoveries.

Obviously the breaking of dormancy of antelope bitterbrush seeds by moist prechilling in the field has very fragile safe site conditions controlling the process. If we add phenotypic and ecotypic variability among seed populations and the Meyer influence of pregermination incubation temperatures, the field model becomes potentially very complex, but still a necessary and most valuable area of research.

\section{Literature Cited}

Evans, R.A., and J.A. Young. 1972. Microsite requirements for establishment of annual rangeland weeds. Weed Sci. 20:350-356.

Evans, R.A., and J.A. Young. 1970. Plant litter and establishment of alien annual weed species in rangeland communities. Weed Sci. 18:697-703.

Evans, R.A., D.A. Easi, D.N. Book, and J.A. Young. 1982. Quadratic response surface analysis of seed-germination trials. Weed Sci. 30:411-416.

Everett, R.L., and R.0. Meeuwig. 1957. Hydrogen peroxide and thiourea treatment of bitterbrush seed. USDA Forest Serv. Intermountain Forest and Range Exp. Sta. Res. Note 196. Ogden, Ut.

Hormay, A.L. 1943. Bitterbrush in California. California Forest and Range Exp. Sta. U.S. Forest Serv. Res. Note. 39.

Kay, B.L., W.L. Graves, and J.A. Young. 1988. Long-term storage of desert shrub seed. Mojave Revegetation Notes. Agronomy and Range Sci. U.C. Davis 23:1-22.

McConnell, B.R. 1960. Effect of gibberellic acid and cold treatments on the germination of bitterbrush. USDA Forest Serv. Pacific Northwest Forest and Range Exp. Sta. Res. Note 187. Portland, Ore.

Meyer, S.E. 1989. Warm pretreatment effects on antelope bitterbrush (Purshia tridentata) germination response to chilling. Northwest Sci. 63:146-153.

Nord, E.C. 1965. Autoecology of bitterbrush in California Ecological Monographs 35:193-194.

Pearson, B.0. 1957. Bitterbrush (Purshia tridentata) seed dormancy broken with thiourea. J. Range Manage. 10:41-42.

Young, J.A., and R.A. Evans. 1981. Germination of seeds of antelope bitterbrush, desert bitterbrush, and cliff rose. ARR-W-17. Sci. Education Admin. USDA. Berkeley, Calif. p. 39.

Young, J.A., and R.A. Evans. 1976. Stratification of bitterbrush seeds. J. Range Manage. 29:421-428.

Young, J.A., and R.A. Evans. 1989. Dispersal and germination of big sagebrush (Artemisia tridentata) seeds. Weed Sci. 37:201-206. 